\title{
ANALISIS MANAJEMEN RISIKO TEKNOLOGI INFORMASI MENGGUNAKAN COBIT 5 (STUDI KASUS: PT GLOBAL INFOTECH)
}

\author{
${\text { Prilly Peshaulia Thenu1, Agustinus Fritz Wijaya }{ }^{2} \text {, Christ Rudianto }}^{3}$ \\ Sistem Informasi - Fakultas Teknologi Informasi \\ Universitas Kristen Satya Wacana \\ email :1682016063@ student.uksw.edu, ${ }^{2}$ agustinus.wijaya@uksw.edu, \\ ${ }^{3}$ chris.rudianto@uksw.edu \\ Salatiga, Indonesia
}

\begin{abstract}
PT Global Infotech Solutions is a company engaged in the field of IT solutions. The company does business by becoming an IT consultant or providing solutions to every customer who has problems including software, hardware and networking systems. Information technology is supporting business in the company, so IT risks can occur at any time. Seeing this problem, management / managing risk is the right way to minimize the potential losses incurred. Therefore, in this study the authors conducted risk management of information technology using COBIT 5. The measurement results of capability level that PT Global Infotech Solutions is at level 1 in managing risk according to the APO12 domain. There are several recommendations given so that risk management can run well.
\end{abstract}

Kata kunci: COBIT 5, IT Risk Management, Capability Level

\begin{abstract}
Abstrak
PT Global Infotech Solutions adalah perusahaan yang bergerak di bidang solusi TI. Perusahaan menjalankan bisnis dengan cara menjadi consultant IT atau memberikan solusi kepada setiap customer yang memiliki masalah meliputi software, hardware and networking system. Teknologi informasi menjadi pendukung jalannya bisnis di perusahaan, sehingga risiko terhadap TI dapat terjadi kapanpun. Melihat permasalahan ini maka manajemen/mengelola risiko adalah cara yang tepat untuk meminimalisasi potensi kerugian yang terjadi. Oleh sebab itu, dalam penelitian ini penulis melakukan manajemen risiko terhadap teknologi informasi dengan menggunakan COBIT 5. Hasil pengukuran capability level bahwa PT Global Infotech Solutions berada pada level 1 dalam mengelola risiko sesuai domain APO12. Terdapat beberapa rekomendasi yang diberikan sehingga manajemen risiko dapat berjalan dengan baik.
\end{abstract}

Kata kunci:COBIT 5,APO12, Manajemen risiko TI, capability level 


\section{PENDAHULUAN}

Penerapan teknologi informasi sangatlah berkembang, dan telah mengambil peran penting terkhususnya dalam dunia bisnis. Pada perusahaan dewasa ini, teknologi informasi tidak hanya diterapkan pada operasional saja melainkan sampai pada proses pengambilan keputusan oleh executive management. Penerapan teknologi informasi juga dapat membantu perusahaan untuk bersaing. Oleh karena itu, teknologi informasi merupakak hal yang harus diperhatikan dan dikelola dengan baik oleh perusahaan untuk mempertahankan bisnis yang dijalankan. Dibalik keuntungan yang diberikan, terdapat kekurangan yaitu risiko yang ditimbulkan saat menggunakan teknologi informasi dapat mengakibatkan kerugian. Risiko akan selalu ada oleh karena itu pengelolaan risiko adalah hal yang tepat untuk meminimalisasi potensi kerugian yang terjadi. PT Global Infotech Solutions adalah perusahaan yang bergerak di bidang solusi TI. Perusahaan menjalankan bisnis dengan cara menjadi consultant IT atau memberikan solusi kepada setiap customer yang memiliki masalah meliputi software, hardware and networking system. Terdapat tiga fokus perusahaan pada customer yakni pertama, membantu dan mendukung setiap customer dalam mengelola operasional teknologi informasi. Kedua, memastikan bahwa kinerja TI baik. Ketiga, mengefektifkan rutinitas sehari-hari atau customer dapat fokus dengan kegiatan utama bisnis mereka. Berdasarkan profil perusahaan di atas, maka teknologi informasi menjadi pendukung jalannya bisnis di perusahaan, sehingga risiko terhadap TI dapat terjadi kapanpun. Oleh sebab itu untuk mengatasi permasalahan di atas maka dalam penelitian ini penulis melakukan manajemen risiko terhadap teknologi informasi dengan menggunakan kerangka kerja COBIT 5.

Berdasarkan penjelasan diatas, maka penulis merumuskan masalah yaitu apa saja risiko teknologi informasi yang ada di perusahaan dan sejauh mana pemanfaatan COBIT 5 dalam memanajemen risiko bagi perusahaan dalam mengelola dan meminimalisir risiko. Tujuan yang ingin dicapai oleh penulis yaitu untuk mengetahui apa saja risiko TI yang ada di perusahaan dan untuk mengetahui sejauh mana pemanfaatan COBIT 5 bagi perusahaan dalam mengelola dan meminimalisir risiko TI. Manfaat dari penelitian ini yaitu dapat menjadi panduan bagi perusahaan dalam mengelola risiko TI yang terjadi sehingga dapat mengurangi kerugian bagi perusahaan.

\section{METODOLOGI PENELITAN}

\subsection{Risiko}

Risiko adalah ketidaktentuan (uncertainty) yang mungkin melahirkan peristiwa kerugian [Djojosoedarso, 2003]. Resiko adalah suatu variasi dari hasil-hasil yang dapat terjadi selama periode tertentu [Arthur \& Richard, 2002].

\subsection{Manajemen risiko teknologi informasi}

Manajemen risiko adalah suatu proses identifikasi, mengukur risiko, serta membentuk strategi untuk mengelolanya melalui sumber daya yang tersedia. Strategi yang dapat digunakan antara lain mentransfer risiko pada pihak lain, menghindari risiko, mengurangi efek buruk dari risiko, dan menerima sebagian maupun seluruh konsekuensi dari risiko tertentu [Wanarta, Celia., Wibowo, Adi., Gunawan, Ibnu. 2013. IT Risk Assessment di PT. X. Jurnal Infra. 1(2): 207-213]. 


\subsection{COBIT (Control Objectives for Information and Related Technology)}

COBIT merupakan kerangka kerja pengendalian internal yang berkaitan dengan teknologi informasi, yang dipublikasikan oleh Information System Audit and Control Foundation di tahun 1996 dan di-update pada tahun 1998 dan 2000. COBIT dibuat dengan tujuan melakukan penelitian dan pengembangan terhadap sekumpulan kontrol teknologi informasi, yang dapat diterima secara internasional bagi kepentingan auditor dan manajer bisnis suatu organisasi. COBIT mengelompokkan semua aktivitas bisnis yang terjadi dalam organisasi menjadi 34 proses yang terbagi ke dalam empat buah domain proses, meliputi :

1. Plan and Organise (10 proses), meliputi strategi dan taktik yang berkaitan dengan identifikasi pemanfaatan IT yang dapat memberikan kontribusi dalam pencapaian tujuan bisnis.

2. Acquire and Implement (7 proses), merupakan domain proses yang merealisasikan strategi IT, serta solusi-solusi IT yang diperlukan untuk diterapkan pada proses bisnis organisasi. Pada domain ini pula dilakukan pengelolaan perubahan terhadap sistem eksisting untuk menjamin proses yang berkesinambungan.

3. Deliver and Support (13 proses), yaitu domain proses yang berhubungan dengan pelayanan yang diberikan, mulai dari operasi tradisional terhadap keamanan dan aspek kesinambungan hingga pelatihan.

4. Monitor and Evaluate (4 proses), merupakan domain yang memberikan pandangan bagi pihak manejemen berkaitan dengan kualitas dan kepatuhan dari proses yang berlangsung dengan kendali-kendali yang diisyaratkan.

\subsection{APO (Align, Plan, Organize)}

COBIT 5 sebuah kerangka kerja generasi terbaru dari panduan ISACA yang membahas mengenai tata kelola dan manajemen TI. COBIT 5 menyediakan kerangka kerja yang membantu perusahaan dalam mencapai tujuan mereka dengan tata kelola dan manajemen teknologi informasi (ISACA,2012). Kerangka kerja COBIT 5 terbagi dalam 5domain, salah satunya adalah APO (Align, Plan, Organize) yang merupakan domain yang digunakan untuk mengidentifikasi cara terbaik bagi tata kelola Teknologi Informasi (TI) untuk berkontribusi dalam pencapaian tujuan perusahaan (ISACA, 2013). Dalam penelitian ini digunakan proses APO 12 yang merupakan pedoman proses mengelola risiko yang secara terus menerus mengidentifikasi, menilai dan mengurangi risiko terkait TI dalam tingkat toleransi yang ditetapkan oleh manajemen eksekutif perusahaan. Proses ini mendukung tercapainya serangkaian tujuan yang berhubungan dengan TI, yang mendukung tercapainya serangkaian tujuan perusahaan. Manajemen risiko perusahaan yang berkaitan dengan TI harus terintegrasi dengan enterprise risk management (ERM) secara keseluruhan. Domain APO12 memiliki 6 subdomain yaitu sebagai berikut:
a. APO12.01 Collect Data / mengumpulkan data
b. APO12.02 Analyse Risk / menganalisis risiko
c. APO12.03 Maintain A Risk Profile
d. APO12.04 Articulate Risk
e. APO12.05 Define a Risk Management Action Portofolio
f. APO12.06 Respond to Risk

Dari domain tersebut dilakukan penilaian capability level yang bertujuan untuk memberikan penilaian yang berbeda dari satu level ke level yang lebih tinggi dan risk assessment, yaitu suatu 
proses untuk mengidentifikasi potensial risiko yang terjadi baik yang berasal dari dalam maupun dari luar yang dihadapi oleh perusahaan atau organisasi. Tujuan dilakukannya risk assessment adalah untuk mengukur seberapa besar risiko yang dihadapi dan seberapa besar dampak terhadap organisasi, sehingga dapat digunakan untuk meminimalisir dampak. Dari risk assessment dapat menentukan mitigasi risiko yang merupakan metode atau cara yang sistematis digunakan untuk mengurangi dampak yang timbul akibat adanya suatu risiko. Strategi dalam melakukan pengurangan risiko misalnya menerima risiko (risk assumption), mencegah risiko (risk avoidance), membatasi level risiko (risk limitation), atau mentransfer risiko (risk transference). (ISACA,2012).

Penelitian sebelumnya yang dilakukan oleh Myrna Dwi Rahmatya, dkk., dengan judul "pengukuran manajemen risiko TI di PT X menggunakan COBIT 5". Penelitian ini bertujuan mengukur manajemen risiko TI PT. X dengan menggunakan capability level COBIT 5, melakukan analisis gap dan memberikan rekomendasi berupa langkah yang dapat dilakukan untuk dapat mencapai manajemen risiko TI yang diharapkan sehingga dapat meminimalisir tingkat kegagalan/kerugian. Hasil analisis manajemen risiko TI pada PT. X berada di level 1 (performed process), yaitu EDM03, APO12, DSS01, DSS05, MEA02. Manajemen risiko TI di PT. X masih belum terorganisir. Sementara itu, capability level yang ingin dicapai ialah level 2 (managed process). Oleh karena itu ada beberapa rekomendasi yang diberikan. [1]

Penelitian sebelumnya terkait dengan manajemen risiko menggunakan COBIT 5 yang dilakukan oleh Yani Iriana Putri, dkk., dengan judul "Penilaian Kapabilitas Penerapan Manajemen Risiko Teknologi Informasi Menggunakan Kerangka Kerja COBIT 5 dengan studi kasus (Studi pada PDAM Kota Malang Jawa Timur)". Tujuan penelitian ini melakukan penilaian kapabilitas penerapan manajemen risiko TI pada PDAM Kota Malang pada proses EDM03 (Ensure Risk Optimisation), APO12 (Manage Risk) dan APO13 (Manage Security). Hasil yang diharapkan mampu menjadi bahan evaluasi bagi perusahaan untuk melakukan perbaikan di masa depan dengan menerapkan rekomendasi yang telah dirumuskan.[2]

Penelitian ini menggunakan metode mixed method. Johnson dan Cristensen (2007) MixMethods atau metode penelitian kombinasi merupakan pendekatan dalam penelitian yang mengkombinasikan atau menghubungkan antara metode penelitian kualitatif dan kuantitatif (mencakup landasan filosofis, penggunaan pendekatan dan mengkombinasikan kedua pendekatan dalam penelitian). Dengan metode pengumpulan data yaitu melakukan wawancara dan penyebaran kuisioner yang mengikuti framework COBIT 5 pada domain APO12. Domain APO12 menyediakan proses yang terstruktur dalam mengelola risiko. 


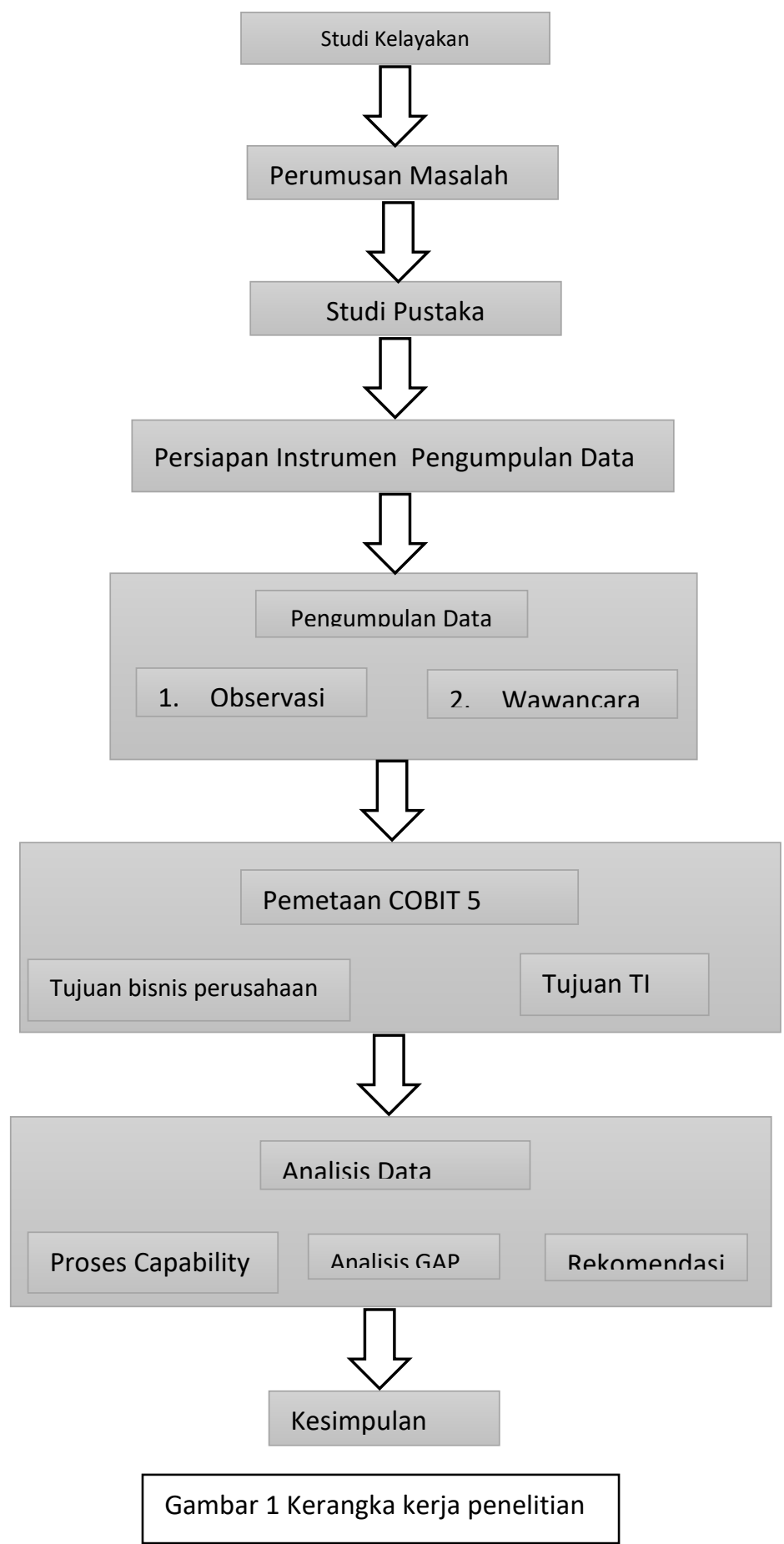

a) Studi kelayakan

Tahapan pertama yang dilakukan yaitu studi kelayakan. Kegiatan yang dilakukan pada studi kelayakan yaitu melakukan wawancara dengan orang yang bertanggung jawab dalam hal ini yaitu VP operation terkait profil perusahaan, kondisi perusahaan sekarang, dan kebijakankebijakan yang dijalankan. Dan melakukan observasi tempat penelitian. Dengan tujuan agar penulis dapat membangun pemahaman mengenai kondisi pada tempat penelitian. 
b) Perumusan masalah

Tahapan kedua yang dilakukan yaitu perumusan masalah. Terkait dengan hasil studi kelayakan yang dilakukan, maka terdapat masalah atau hal yang harus diperbaiki. Sehingga dilakukan perumusan masalah yang akan menjadi topik dari penelitian.

c) Studi pustaka

Tahapan ketiga yang dilakukan yaitu studi pustaka. Studi pustaka adalah mempelajari berbagai buku referensi serta hasil penelitian serta hasil penelitian sebelumnya yang sejenis yang berguna untuk mendapatkan landasan teori mengenai masalah yang akan diteliti. (Sarwono: 2006)

Tahap ini penulis melakukan studi literature terhadap berbagai jenis buku, jurnal, dan teori mengenai manajemen risiko teknologi informasi, Dengan tujuan untuk dapat memperkuat dasar dalam melakukan penelitian dan sekaligus menentukan metode penelitian yang akan digunakan.

d) Persiapan instrumen pengumpulan data

Tahapan keempat yang dilakukan yaitu persiapan instrumen pengumpulan data. Kegiatan yang dilakukan pada tahap ini yaitu menyiapkan daftar pertanyaan sesuai dengan domain APO 12 .

e) Pengumpulan data

Pengumpulan data dengan metode kualitatif. Dua proses yang dilakukan pada tahap pengumpulan data yaitu observasi dan wawancara. Observasi dilakukan untuk melihat secara langsung proses yang terjadi. Berikutmya melakukan wawancara terhadap setiap orang sudah ditentukan menggunakan analisis RACI. Data yang digunakan terdiri dari data primer dan data sekunder. Data primer berasal dari hasil wawancara tentang domain APO12. Sedangkan data sekunder berasal dari publikasi perusahaan di internet. Proses yang dilakukan terbagi dua yaitu observasi dan wawancara.

f) Pemetaan COBIT 5

Terdapat 2 proses yaitu tujuan bisnis perusahaan, tujuan TI dan proses IT.

- Analisis tujuan bisnis perusahaan menggunakan alat ukur yang tersedia dalam COBIT yaitu enterprise goals.

- Analisis tujuan TI dilakukan dengan tujuan untuk melihat sejauh mana perusahaan menyelaraskan antara tujuan bisnis dan tujuan TI.

g) Analisis data

Tahapan keenam, melakukan clearing data hasil wawancara mengikuti panduan COBIT 5 domain APO12. Ada tiga proses yang dilakukan yaitu mengukur capability level, analisis GAP dan rekomendasi.

- Mengukur capability level : Tahap kelima yaitu proses capability model yang memiliki 6 level yaitu level 0 sampai level 5 . Capability model memiliki proses yang dinyatakan dalam bentuk atribut proses yang dikelompokkan ke dalam tingkatan yang di tentukan berdasarkan pecapaian atribut proses tertentu [3]. Berikut penjelasan setiap levelnya:

Level 0 Incomplete Process merupakan proses dalam tujuan prosesnya tidak dilaksanakan dan gagal dalam pencapaiannya.

Level 1 Performed Process merupakan proses untuk mencapai tujuan bisnisnya perlu diimplementasikan. 
Level 2 Managed Process merupakan proses yang hasilnya ditetapkan dan dikontrol dan juga diimplementasikan juga dikelola (planned, monitored and adjusted).

Level 3 Established Process merupakan proses adanya dokumentasi dan memiliki hasil yang dikomunikasikan (untuk efisiensi organisasi).

Level 4 Predictable Process merupakan proses yang dimonitor, kemudian diukur dan diprediksi untuk mencapai hasil.

Level 5 Optimizing Process merupakan proses yang nantinya akan relevan dengan tujuan bisnis yang akan datang sehingga dapat diprediksikan kemudian ditingkatkan untuk memenuhi tujuan bisnis. [4]

- Analisis GAP: Pada proses ini membandingkan hasil dari pengukuran capability model dengan kondisi yang diharapkan.

- Berdasarkan hasil temuan yang dilakukan pada tahap analisis data maka penulis memberikan rekomendasi terhadap perusahaan terkait pengelolaan teknologi informasi.

h) Kesimpulan

Kesimpulan diambil berdasarkan hasil yang telah diperoleh.

Raci Chart diperlukan untuk menentukan siapa yang akan menjadi narasumber dalam penelitian yang dilakukan ini. Raci adalah singkatan Responsible, Accountable, Consulted and Informed. COBIT 5 menjelaskan RACI chart adalah matriks keseluruhan aktivitas atau otorisasi pendukung keputusan yang harus diambil dalam suatu organisasi dengan dikaitkan dengan seluruh pihak atau posisi yang terlibat

Tabel 1. Pemetaan RACI CHART

RACI Jabatan

\begin{tabular}{ll}
\hline $\mathbf{R}$ & VP Operation \\
$\mathbf{A}$ & Managing Director \\
$\mathbf{C}$ & Managing Director \\
$\mathbf{I}$ & Human Capital Officer
\end{tabular}

\section{HASIL DAN PEMBAHASAN}

Tahapan ini lakukan sesuai dengan metodologi penelitian yang sudah dipaparkan.

Tahap pertama yang dilakukan yaitu melakukan pemetaan tujuan bisnis perusahaan sesuai dengan panduan pada COBIT yaitu enterprise goals yang akan ditampilkan pada gambar di bawah. 


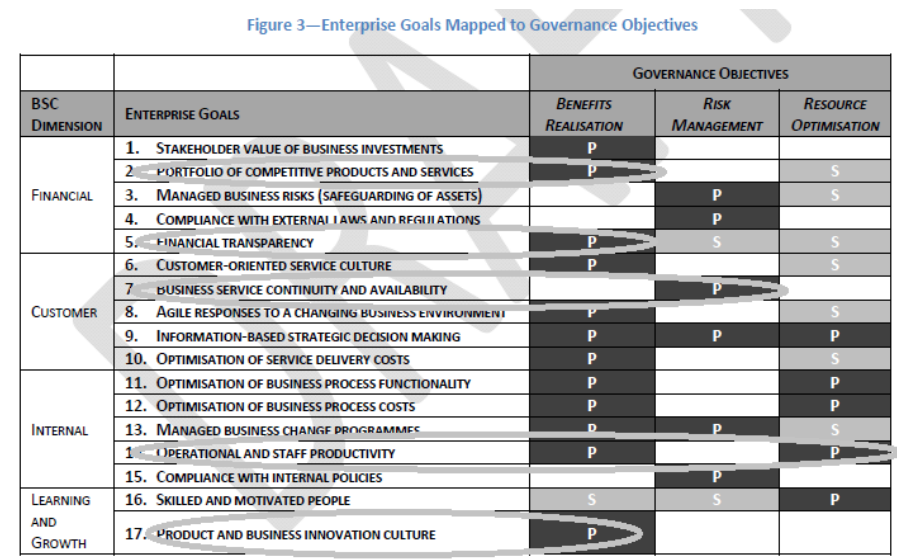

Gambar 2. Enterprise goals sesuai dengan PT Global Infotech

\begin{tabular}{|c|c|c|c|c|}
\hline $\begin{array}{l}\text { Tujuan PT Global } \\
\text { Infotech Solution }\end{array}$ & No & $\begin{array}{l}\text { Tujuan } \\
\text { Enterprise }\end{array}$ & $\begin{array}{l}\text { BSC } \\
\text { Dimension }\end{array}$ & Relationship \\
\hline \multirow{4}{*}{$\begin{array}{l}\text { Memberikan } \\
\text { solusi canggih } \\
\text { yang dapat } \\
\text { memudahkan } \\
\text { kehidupan orang } \\
\text { - Memenuhi } \\
\text { kebutuhan } \\
\text { pelanggan } \\
\text { dengan } \\
\text { mengelola dan } \\
\text { mempertahankan } \\
\text { layanan yang } \\
\text { terbaik } \\
\text { - Memberikan } \\
\text { layanan terbaik } \\
\text { yang } \\
\text { dikembangkan } \\
\text { dengan } \\
\text { semangat dan } \\
\text { upaya yang } \\
\text { besar secara } \\
\text { terus menerus } \\
\text { dan cepat }\end{array}$} & 2 & $\begin{array}{l}\text { Portfolio of } \\
\text { competitive } \\
\text { products } \\
\text { and } \\
\text { services }\end{array}$ & Financial & Primary \\
\hline & 7 & $\begin{array}{l}\text { Business } \\
\text { service } \\
\text { continuity } \\
\text { and } \\
\text { availability }\end{array}$ & Customer & Primary \\
\hline & 14 & $\begin{array}{l}\text { Operational } \\
\text { and staff } \\
\text { productivity }\end{array}$ & Internal & Primary \\
\hline & 17 & $\begin{array}{l}\text { Product } \\
\text { and } \\
\text { business } \\
\text { innovation } \\
\text { culture }\end{array}$ & $\begin{array}{l}\text { Learning } \\
\text { and } \\
\text { growth }\end{array}$ & Primary \\
\hline
\end{tabular}

Tabel 2. Rangkuman pemetaan tujuan bisnis ke dalam enterprise goals 
Tahap berikutnya yaitu pemetaan tujuan bisnis perusahaan ke dalam tujuan TI sesuai panduan COBIT 5 yaitu enterprise goals - IT related goals pada gambar berikut.

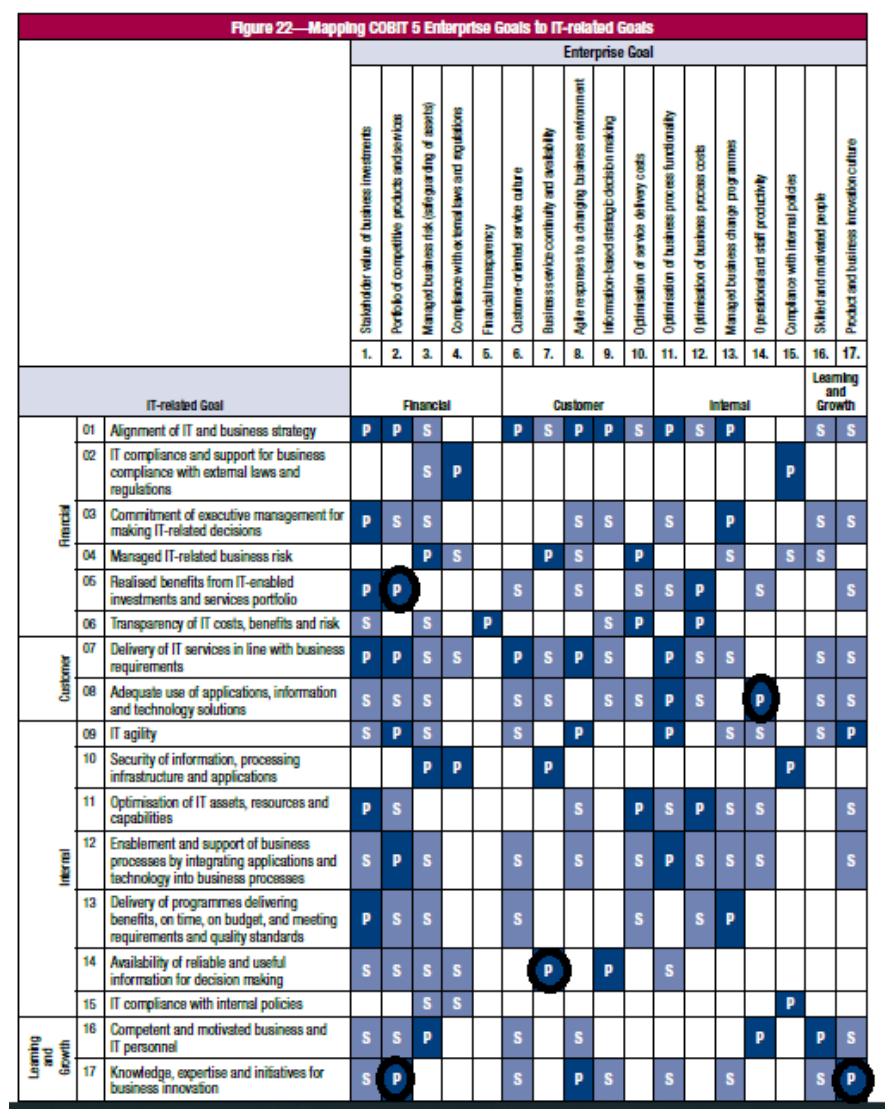

Gambar 3. Pemetaan Enterprise goals - IT related goals

a. Proses capability

Hasil wawancara dari proses APO12 adalah ada atau tidaknya aktivitas tersebut dan akan ditinjau lebih untuk mengukur tingkat capability level.

- APO12 - 01 Collect data: deskripsi dari Base Practice 01 pada APO 12 adalah mengumpulkan data. VP Operation menjelaskan perusahaan telah membuatkan list kejadian terjadinya unplanned activities berkaitan dengan infrastructure TI, dan sebagian besar adalah karena risiko infrastruktur.

- APO 12 - 02 Analyse risk: deskripsi dari base practice 02 pada APO 12 adalah menganalisis risiko. VP operation menjelaskan setiap risiko yang terjadi di perusahaan dipastikan dapat diatasi dengan dilakukan pencatatan kejadian terjadinya unplanned activities setiap tahunnya. Adapun fungsi kontrol yang dilakukan untuk mengurangi risiko yaitu review access yang dilakukan oleh human resource/HR pada saat proses employee onboarding dan outboarding, penggunaan cloud storage dan pengujian secara berkala.

- APO 12 - 03 Maintain a risk profile: deskripsi dari base practice 03 pada APO 12 adalah memelihara profil risiko. VP operation menjelaskan bahwa network connection dan file server merupakan layanan TI dan sumber daya infrastruktur TI yang penting untuk mempertahankan proses bisnis operasional. Setiap informasi tentang peristiwa risiko TI yang telah terwujud juga dimasukkan ke dalam profil risiko TI dari perusahaan. 
- APO 12 - 04 Articulate risk: deskripsi dari base practice 04 pada APO 12 adalah mengartikulasikan risiko. VP operation menjelaskan bahwa hasil analisis risiko dilaporakn kepada semua stakeholder yang terkena dampak dan hasil audit internal juga dikaji ulang untuk analisis risiko tambahan.

- APO 12 - 05 Defined a risk management action portfolio: deskripsi dari base practice 05 pada APO 12 adalah menentukan portfolio aksi manajemen risiko. VP operation menjelaskan fungsi kontrol yang dilakukan perusahaan merupakan hasil dari memelihara penyimpan kontrol yang sesuai untuk mengelola risiko yang mungkin terjadi.

- APO 12 -06 Respond to risk: deskripsi dari base practice 06 pada APO 12 adalah melakukan respon terhadap risiko. VP operation menjelaskan setiap kejadian yang terjadi di masa lalu dikaji ulang untuk ditentukan penyebabnya setelah itu akan digunakan menjadi kebutuhan respon risiko tambahan yang tepat dan perbaikan risiko.

Berdasarkan paparan penjelasan diatas maka hasil yang diperoleh untuk proses APO12 yaitu dalam mengelola risiko, PT global infotech berada pada level 1 dengan kriteria secara garis besar tercapai / largely achieved.

\section{b. Analisis GAP}

Nilai GAP yang terjadi pada level ini dan level target adalah 1. Agar proses domain APO12 memenuhi level 2 maka beberapa hal yang harus diperhatikan untuk mencapai level 2:

- Membentuk sebuah manajemen khusus untuk mengelola risiko sehingga pengontrolan terhadap manajemen risiko dilakukan dengan baik dan tepat.

- Membuat dokumen yang spesifik tentang identifikasi risiko beserta skenario TI yang tepat untuk mengatasi risiko agar tidak terjadi dan evaluasi terhadap manajemen risiko.

Adapun identifikasi risiko berserta dampak yang dilakukan sebagai risk assessment dapat dilihat pada tabel berikut.

\begin{tabular}{|c|c|c|c|c|c|c|c|}
\hline \multirow{2}{*}{ SUMBER RISIKO } & \multirow{2}{*}{ RISIKO } & \multicolumn{3}{|c|}{ FREKUENSI KEJADIAN } & \multicolumn{3}{|c|}{ DAMPAK } \\
\hline & & $\mathrm{s}$ & $\mathrm{K}$ & TP & $\mathrm{B}$ & 5 & $\mathrm{k}$ \\
\hline \multirow[t]{5}{*}{ Alam. } & Gempa bumi & & & $\mathrm{x}$ & & & \\
\hline & Radiasi panas. & & & $\mathrm{x}$ & & & \\
\hline & Rebu/kotorana & & $\mathrm{x}$ & & & & $\mathrm{x}$ \\
\hline & Kelembaban & & & $\mathrm{x}$ & & & \\
\hline & \begin{tabular}{|l|l|} 
Kebaakaran \\
\end{tabular} & & & $\mathrm{x}$ & & & \\
\hline \multirow[t]{8}{*}{ Manusia. } & 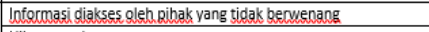 & & & $\mathrm{x}$ & & & \\
\hline & Hilangoxxa data & & & $\mathrm{x}$ & & & \\
\hline & Human eroh & & & $\mathrm{x}$ & & & \\
\hline & Data dan inforcmasi tidak sesuai fakta & & & $\mathrm{x}$ & & & \\
\hline & Mantan karvawan/user masihh memilki akses inforcmasi. & & & $\mathrm{x}$ & & & \\
\hline & \begin{tabular}{|l|} 
Kebecosoran inforomass atau data \\
\end{tabular} & & & $\mathrm{x}$ & & & \\
\hline & Kecrysakan akibat ylah manousia sepertic cybercrime, bembaiakan & & & $\mathrm{x}$ & & & \\
\hline & Tidak mengaganti yserb LIR & & & $\mathrm{x}$ & & & \\
\hline \multirow{8}{*}{ Sistem dan lafrastruktur } & Server down & & $x$ & & $\mathrm{x}$ & & \\
\hline & Konekssi iariogan tecrputus & & & $\mathrm{x}$ & & & \\
\hline & \begin{tabular}{|l|l} 
Gagal update \\
\end{tabular} & & & $\mathrm{x}$ & & & \\
\hline & \begin{tabular}{|l|l} 
Kercusakaka hardware \\
\end{tabular} & & $x$ & & $\mathrm{x}$ & & \\
\hline & \begin{tabular}{|l|} 
Backup failure \\
\end{tabular} & & & $\mathrm{x}$ & & & \\
\hline & \begin{tabular}{|l} 
Tecinovekssi virus \\
\end{tabular} & & & $\mathrm{x}$ & & & \\
\hline & \begin{tabular}{|l|} 
Data corrupt \\
\end{tabular} & & & $\mathrm{x}$ & & & \\
\hline & Kurang bajikoxa kualitas.jariogan & & $\mathrm{x}$ & & & $\mathrm{x}$ & \\
\hline Keterarogara frekkkej & Keterapogan dampak: & & & & & & \\
\hline $\begin{array}{l}\text { Sisering } \\
\text { Ki:Kadanag-kadang } \\
\text { TR.itidak Bernah }\end{array}$ & $\begin{array}{l}\text { B: Besar } \\
\text { S: Sedang } \\
\mathrm{K} \text { : Kecil }\end{array}$ & & & & & & \\
\hline
\end{tabular}

c. Mitigasi risiko

Proses selanjutnya yaitu melakukan mitigasi berdasarkan hasil identifikasi risiko pada PT global infotech. Terdapat empat risiko yang terjadi yang memberi dampak dari kecil, sedang hingga besar diantaranya yaitu risiko debu/kotoran yang bersumber dari alam, server down yang bersumber dari sistem, kerusakan hardware yang bersumber dari insfrastruktur dan 
kurang baiknya kualitas jaringan yang bersumber dari instrastruktur dan sistem. Pada tabel berikut dijelaskan langkah mitigasi risiko.

\begin{tabular}{|l|l|l|}
\hline \multicolumn{3}{|l|}{ Langkah mitigasi risiko debu/kotoran } \\
\hline Manusia & Proses & Teknologi \\
\hline Memberikan & Memberikan & - \\
sebuah & SOP yang & \\
tanggung & mengacu pada & \\
jawab kepada & pemeliharaan & \\
1 OB yang & infrastruktur & \\
dipercayakan & TI yang baik & \\
khusus untuk & & \\
membersihkan & & \\
infrastruktur & & \\
TI secara rutin & & \\
\hline
\end{tabular}

\begin{tabular}{|l|l|l|}
\hline \multicolumn{2}{|l|}{ Langkah mitigasi server down } \\
\hline Manusia & Proses & Teknologi \\
\hline Memberikan & Mengecek & - \\
tanggung & koneksi & \\
jawab kepada & internet dan & \\
1 atau & rutin & \\
beberapa & menghapus & \\
orang untuk & cache \& & \\
mengelola & cookies & \\
infrastruktur & & \\
\hline
\end{tabular}

\begin{tabular}{|l|l|l|}
\hline \multicolumn{3}{|l|}{ Langkah mitigasi kerusakan hardware } \\
\hline Manusia & Proses & Teknologi \\
\hline $\begin{array}{l}\text { Memberikan } \\
\text { tanggung }\end{array}$ & $\begin{array}{l}\text { Mengecek } \\
\text { barang secara } \\
\text { jawab kepada } \\
\text { fisik maupun } \\
\text { bagian IT }\end{array}$ & - \\
untuk & setiap aplikasi \\
dan data yang & \\
hardenance & terdapat di \\
ada & dalamnya & \\
\hline
\end{tabular}




\begin{tabular}{|l|l|l|}
\hline \multicolumn{3}{|l|}{ Langkah mitigasi kurang baiknya kualitas jaringan } \\
\hline Manusia & Proses & Teknologi \\
\hline Memberikan & Mengecek & - \\
tanggung & kecepatan & \\
jawab ke & jaringan dan & \\
bagian IT & koneksi & \\
untuk & & \\
mengecek & & \\
kualitas & & \\
jaringan & & \\
\hline
\end{tabular}

\section{KESIMPULAN}

Berdasarkan hasil penelitian dan analisis risiko teknologi informasi pada PT global infotech solutions, maka dapat diambil kesimpulan sebagai berikut:

- Terdapat empat risiko yang terjadi yang memberi dampak dari kecil, sedang hingga besar diantaranya yaitu risiko debu/kotoran yang bersumber dari alam, server down yang bersumber dari sistem, kerusakan hardware yang bersumber dari insfrastruktur dan kurang baiknya kualitas jaringan yang bersumber dari instrastruktur dan sistem. Pada tabel berikut dijelaskan langkah mitigasi risiko.

- Hasil dari pengukuran capability level pada COBIT 5 untuk manajemen risiko yaitu APO12 (Manage Risk) berada pada level 1. Kurangnya pengontrolan terhadap risiko TI dan pendokumentasian yang spesifik mengenai skenario TI dari perusahaan yang baik.

- Hasil analisis risiko terdapat 4 risiko dengan frekuensi kejadian tergolong kadang-kadang terjadi dan dampak yang timbulkan dari kecil hingga besar.

- Terdapat dua rekomendasi untuk perusahaan dalam mengelola risiko yang lebih tepat yaitu pertama, membentuk sebuah manajemen khusus untuk mengelola risiko sehingga pengontrolan terhadap manajemen risiko dilakukan dengan baik dan tepat. Kedua, membuat dokumen yang spesifik tentang identifikasi risiko beserta skenario TI yang tepat untuk mengatasi risiko agar tidak terjadi dan evaluasi terhadap manajemen risiko.

- Manfaat penerapan COBIT 5 di perusahaan dapat terlihat dari hasil rekomendasi yang telah dipaparkan sebelumnya. 


\section{Referensi}

[1] Megawati, dkk,. (2018). "Evaluasi Manajemen Risiko Teknologi Informasi Menggunakan Kerangka Kerja COBIT 5.0". Jurnal Ilmiah Rekayasa dan Manajemen Sistem Informasi, Vol. 4, No. 2. Pekanbaru.

[2] ISACA. (2012). COBIT 5 Implementation, Rolling Meadows. Jakarta: ISACA.

[3] Widilianie Eka., Manuputty David Augie. (2019). "Evaluasi Kinerja Si Project Management Menggunakan Framework Cobit 5 Subdomain MEA 01". Jurnal SITECH, Vol 2, No 1. Salatiga.

[4] Rini, Astuti. (2018). "Implementasi Manajemen Risiko Sistem Informasi Menggunakan Cobit 5". Media Informatika Vol.17 No.1. Bandung.

[5] Megawati., Mimi, Kazmaini. (2018). “Analisa Manajemen Resiko Sistem Informasi Perpustakaan Menggunakan Cobit 4.1 Pada Domain PO9". Jurnal Ilmiah Rekayasa dan Manajemen Sistem Informasi, Vol. 4. Pekanbaru.

[6] Setyaningrum Dwi Novia, dkk., (2018). "Evaluasi Manajemen Risiko Teknologi Informasi Menggunakan Framework COBIT 5 (Studi Kasus : PT. Kimia Farma (PERSERO) Tbk Plant Watudakon". Jurnal Pengembangan Teknologi Informasi dan Ilmu Komputer, Vol. 2,No.1. Malang.

[7] ISACA. (2011). COBIT 5 Process Ref Guide ED. Jakarta: ISACA.

[8] ISACA. (2012). Process Assessment Model (PAM) Using COBIT 5. Jakarta: ITGI. 